\author{
Vlada M. Gašić \\ Assistant Professor \\ University of Belgrade \\ Faculty of Mechanical Engineering
}

Aleksandar S. Ćoćić

Assistant Professor University of Belgrade

Faculty of Mechanical Engineering

Nina M. Anđelić

Professor

University of Belgrade

Faculty of Mechanical Engineering

\section{Consideration of the Horizontal Inertial Effects at Cantilever Beams with Non- uniform Open Sections}

The problem of torsion due to horizontal inertial effects is considered at cantilever beam with variable I-section. Linear variation of height is concerned as most practical one for the design of cantilever beams. The solution for adopted cases of beams is obtained numerically, according to the complexity of the given ordinary differential equation which deals with pure torsion along with warping torsion. The models are based on known tailor-made beams with possibility for application in design of jib cranes, as practical aspect of this work. The comparison of results is done with uniform cantilever beam models which can be used as one way for verification of stress state of variable cantilever beams subjected to bending with torsion. The obtained results show corresponding advantages of usage of variable sections.

Keywords: Inertia, thin-walled open variable section, torsion, warping, bending.

\section{INTRODUCTION}

The inertial effects are the second type of loads in structural analysis of material handling machines, besides the basic loads such as weights of payload and structural elements. The loads due to inertial effects occur during the movement of different part of machines. Inspite of the fact that some of these loads belong to the class of dynamic loads, they are implemented as quazi-static cases in calculation of structures.

The another point in structural analysis is definition of static model which has to consider a lot of parameters such as type of material, type of section, type of model etc...

The emphasis here is on the usage of variable cross section elements in structural systems which is present since the beginning of the industrialization. In early stages, it was strongly connected with limits of production technology for steel beams [1], which forced engineers to tailor beams with existing ones. Nowadays, the variation in beam cross section is mostly related to the optimization due to reduction of the weight as the goal.

The variation of the cross section can be in one or two directions (height, width or both) with linear or parabolic mode [2]. However, the most practical variation is linear variation of beam height which will be also addressed in this paper. This positive effect for beam carrying capacity due to bending is obvious and authors will not underline this furthermore.

The basis for cross section variation will be carried out at I-section beam which is a standard structural

Received: January 2018, Accepted: March 2018

Correspondence to: Dr Vlada Gašić

Faculty of Mechanical Engineering,

Kraljice Marije 16, 11120 Belgrade 35, Serbia

E-mail: vgasic@mas.bg.ac.rs

doi:10.5937/fmet1803342G

(C) Faculty of Mechanical Engineering, Belgrade. All rights reserved element with wide application in material handling machines. Although this section has allocation appropriate for bending over section major axis, it belongs to the class of "open" thin-walled sections which are highly sensitive to torsional effects. The one view to the optimization of uniform I-section beam due to torsional effects, considering minimum mass (minimum section area) as a goal, is given in $[3,4]$.

The torsion of I-section beams can occur with loads such as inertia in horizontal direction or wind in outdoor structural systems. Faced with such loads, the designer needs to evaluate the magnitudes of the torsional effects and to consider the resistance of the member under the combined bending and torsion. Typical design problem which complies with previous notes is design of outdoor foot mounted jib crane, fig.1. In some circumstances, torsional effects (with significant torsional moment) lead to redesign of the beam into "closed" structural hollow section.

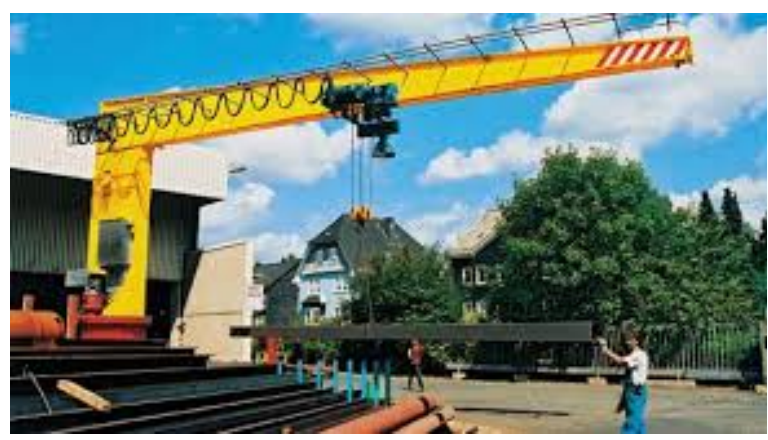

Figure 1. Foot-mounted jib crane

The aim of this paper is to describe the problem of torsional effects on variable I-section cantilever beam subjected to inertial effects in horizontal plane due to tangential acceleration of the payload while rotation. However, this brings the problem into the field of warping torsion of open sections. Warping torsion on 
variable open section is probably unfamilliar to most structural engineers, due to scarce literature in that field of structural analysis.

Also, this paper gives some practical aspects for the designers of cantilever girders such as long span jib crane where this postulation needs to be performed due to safety check.

\section{WARPING TORSION AT OPEN SECTIONS}

The torsional performance of open structural section distinguishes St Venant torsional effects (pure torsion) and warping torsional effects. The interaction between these two types depends on parameters of the cross section, loads and element length. The classical formulation for open thin-walled sections subjected to torsion was developed by Vlasov [5].

At any point in the span, the torsion is defined with the expression

$$
M=M_{t}+M_{w}
$$

where $M_{t}$ is St Venant torsional moment and $M_{w}$ is warping moment.

These two values can be determined with formulation of deflected shape of the beam given by the following ordinary differential equation (ODF)

$$
\theta^{\prime \prime}-\frac{G I_{t}}{E I_{w}} \theta=-\frac{M}{E I_{w}},
$$

where:

$$
\begin{aligned}
& I_{t} \text { - torsional constant, } \\
& I_{w} \text { - warping constant, } \\
& G \text { - shear modulus, } \\
& E \text { - modulus of elasticity and } \\
& \theta=\theta(z) \text { - rotation per unit length. }
\end{aligned}
$$

The boundary conditions arise from the fact that the beam is fixed at one end, while it is free at the other, which leads to

$$
\theta(0)=0, \theta^{\prime}(L)=0,
$$

where $L$ is the beam length.

The problem arises with complexity with nonuniform sections as it will be addressed here.

\subsection{Warping torsion at variable open sections}

In the case of uniform cross sections, $I_{t}$ and $I_{w}$ have constant values and the solution of the differential equation (2) can be obtained analytically. Determination of variable section problem needs numerical analysis for specific beam models.

The linear variation of height $h=h(z)$ is assumed to be with known values of section height at the clamped end, $h_{1}$, and section height at the free end, $h_{2}$ (Fig.2). The heights of I-beam cross section are measured between the centerlines of flanges.

The torsional constant is given by

$$
I_{t}=\frac{1}{3}\left(2 b t_{f}^{3}+h(z) t_{w}^{3}\right)
$$

where: $b$ - beam width,

$t_{f}$ - flange thickness and

$t_{w}$ - web thickness.

The warping constant can be determined with the normalized warping function as

$$
I_{w}=\frac{1}{24} t_{f} b^{3} h(z)^{2}
$$

Therefore, for variable cross sections considered in this paper, where $I_{t}=I_{t}(z)$ and $I_{w}=I_{w}(z)$, shooting method [6] for solving this boundary value problem is applied. This method is implemented in the code written in Python programming language, using appropriate modules and functions from SciPy package, [7].

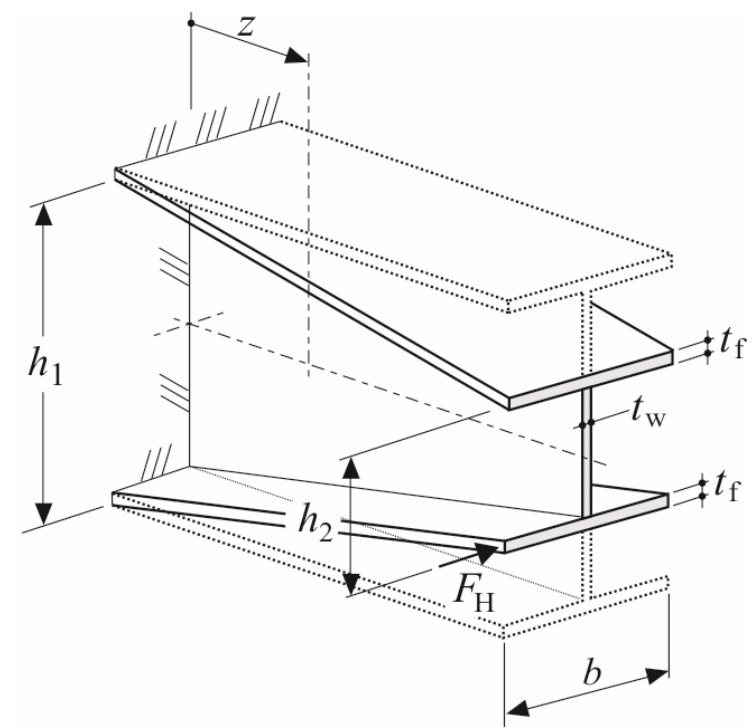

Figure 2. Linear variation of the l-beam section

The brief postulation is given in [8], where the title problem is described in general formulation. The operational torsional moment is chosen to bring only the character of the responses of the calculated beams.

The torsional moment in this paper will be adopted per each case of beam model, according to the horizontal inertial force applied at the cantilever outreach.

\section{CANTILEVER BEAM MODELS}

The solution of (2) will be obtained for several models of the cantilever beam. With respect to practical aspects of this work, the results will be obtained for cantilever beam models with the length of $L=6 \mathrm{~m}$. According to authors, this can be established as starting length where inclusion of linear variation of beam height can give benefits versus increased costs due to manufacturing process of such beam.

The moduli are taken as $G=8000 \mathrm{kN} / \mathrm{cm}^{2}$ and $E=21000 \mathrm{kN} / \mathrm{cm}^{2}$, i.e. for construction steel material. There are calculated 6 cases, with parameters given in Table 1. The parameters are relying on technical characteristics of IPE sections, where data correspond to "tailor" modus of sizes 160, 200, 240, 300, 400, 500, respectivelly to cases (Fig.3). The IPE sections are very common in structures of jib cranes. Additionally, they are not sensitive for influence of local bending of the lower flange of the I-section [9]. 


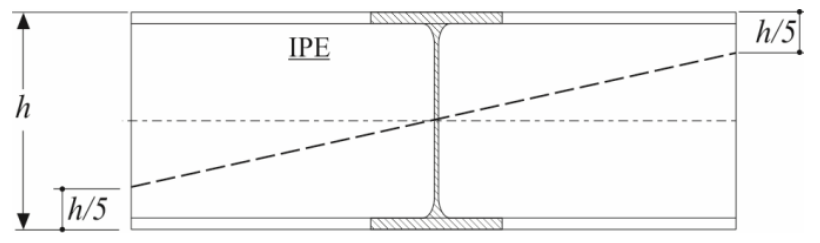

Figure 3. Production modus for variaton of I-beam

\subsection{Torsional moments due to inertial effects}

The inertial effects in the horizontal plane occur while beginning or stopping the rotation of the cantilever beam. The tangential acceleration of the beam free end are in the range of $a_{\min }=0,1 \mathrm{~m} / \mathrm{s}^{2}$ and $a_{\max }=0,6 \mathrm{~m} / \mathrm{s}^{2}$. Thus, this will be the boundary values for determination of horizontal inertial force $F_{\mathrm{H}}$ (Fig.2) which acts on the bottom flange of the I-section, with intensity proportional to mass of the payload.

Moreover, one should respect the fact that beam carrying capacity is in direct relation with payload weight which produces major flexural moment of the cantilever clamped end. Here, it is taken the mass of payload which produces normal stresses with reserve of $50 \%$ of allowable stress. In this manner, it is also concerned the influence of the bending due to horizontal force in overall stress check.

The torsional moment arises from the $F_{\mathrm{H}}$ which acts over centroid of sections. The calculation is two-folded. It is concerned torsional moment due to inertial effects, on variable section, within the boundary acceleration values noted as $\mathrm{V}_{1}$ and $\mathrm{V}_{6}$. Parallel to these cases the solution is obtained to corresponding torsional moments acting on the uniform section (which assures same bending stresses at clamped end of the beam) and are noted as $U_{1}$ and $U_{6}$. The uniform section has height of $h_{1}$.

Thus, torsional moments are noted according to type of section- variable/uniform and boundary values of acceleration. The parameters of the models and loads are given in Table 1.

\section{Table 1. Beam models and postulation of load cases}

\begin{tabular}{|c|c|c|c|c|c|c|c|c|c|c|c|}
\hline & \multicolumn{8}{|c|}{ Variable section } & \multicolumn{3}{|c|}{ Uniform section } \\
\hline & \multicolumn{6}{|c|}{$h=h(z)$} & $\mathrm{V}_{1}$ & $\mathrm{~V}_{6}$ & $h=h_{1}$ & $\mathrm{U}_{1}$ & $\mathrm{U}_{6}$ \\
\hline & $h_{1}$ & $h_{2}$ & $b$ & $t_{f}$ & $t_{w}$ & $L$ & $M_{\mathrm{V} 1}$ & $M_{\mathrm{V} 6}$ & $\gtrsim$ & $M_{\mathrm{U} 1}$ & $M_{\mathrm{U} 6}$ \\
\hline CASE & {$[\mathrm{cm}]$} & {$[\mathrm{cm}]$} & {$[\mathrm{cm}]$} & {$[\mathrm{cm}]$} & {$[\mathrm{cm}]$} & {$[\mathrm{cm}]$} & {$[\mathrm{kNcm}]$} & {$[\mathrm{kNcm}]$} & . & {$[\mathrm{kNcm}]$} & {$[\mathrm{kNcm}]$} \\
\hline I & 24.86 & 5.66 & 8.2 & 0.74 & 0.5 & 600 & 0.07 & 0.45 & क्षे & 0.33 & 1.97 \\
\hline II & 31.15 & 7.15 & 10 & 0.85 & 0.56 & 600 & 0.17 & 1.00 & ह్ & 0.72 & 4.35 \\
\hline III & 37.42 & 8.62 & 12 & 0.98 & 0.62 & 600 & 0.33 & 1.98 & 莺 & 1.43 & 8.59 \\
\hline IV & 46.93 & 10.93 & 15 & 1.07 & 0.71 & 600 & 0.72 & 4.35 &. & 3.11 & 18.68 \\
\hline $\mathrm{V}$ & 62.65 & 14.65 & 18 & 1.35 & 0.86 & 600 & 2.00 & 11.99 & $\stackrel{\infty}{\dot{0}}$ & 8.55 & 51.28 \\
\hline VI & 78.40 & 18.40 & 20 & 1.6 & 1.02 & 600 & 4.28 & 25.67 & 0 & 18.2 & 109.4 \\
\hline
\end{tabular}
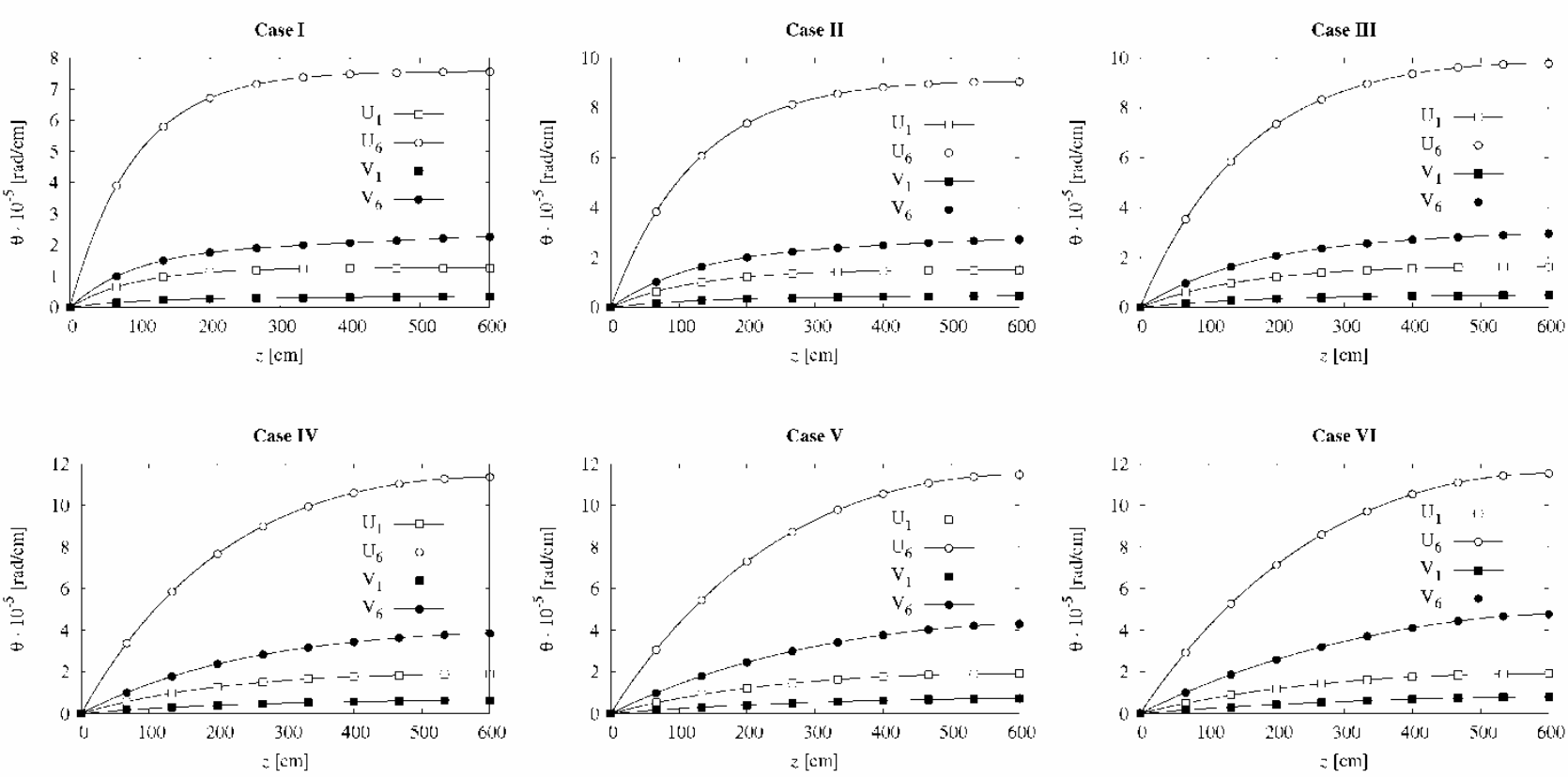

Figure 4. Rotation per unit length

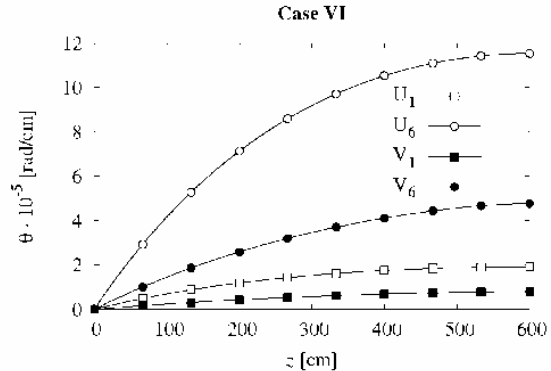



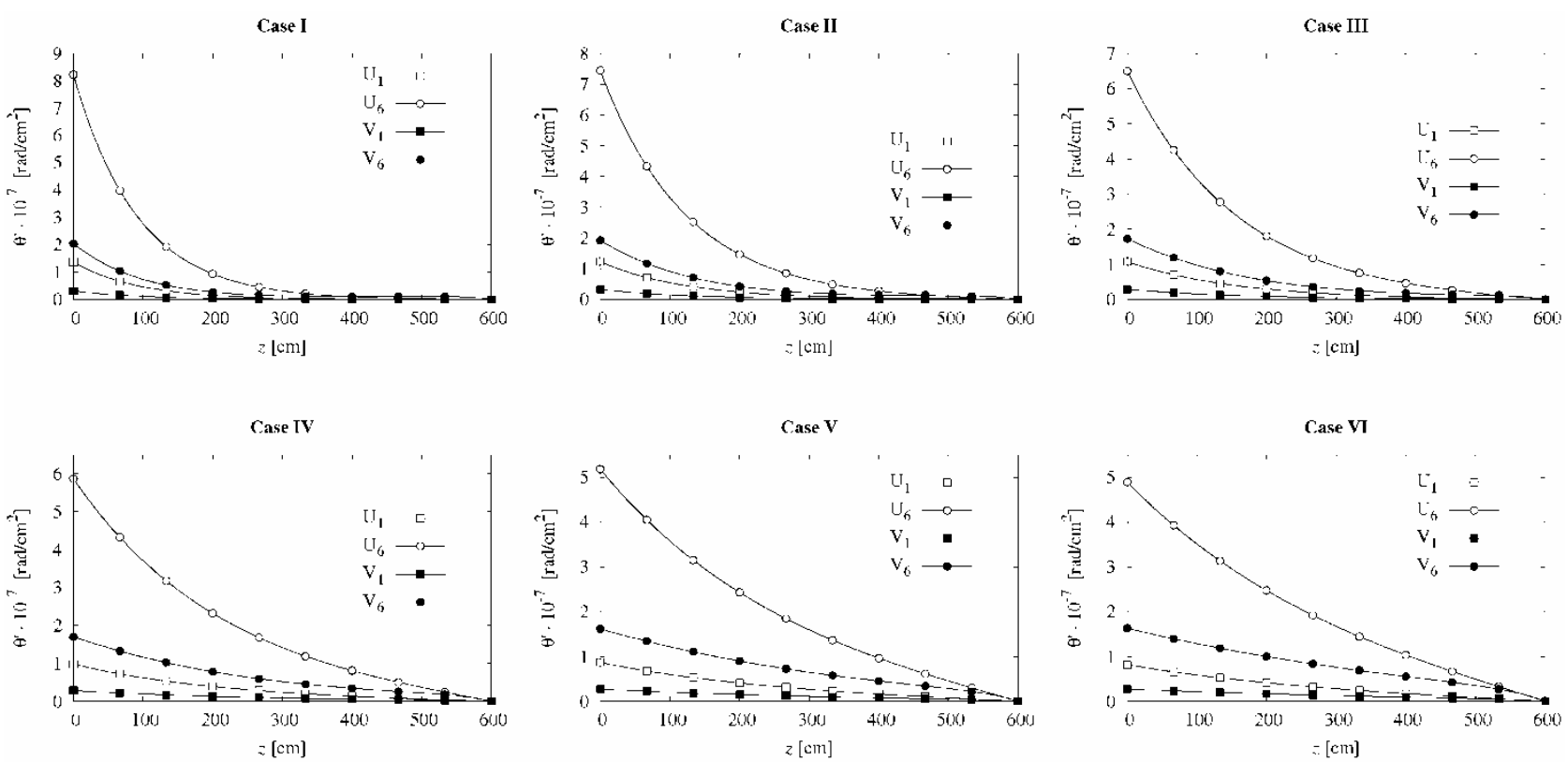

Figure 5. First derivate of the rotation per unit length

\section{NUMERICAL RESULTS AND DISCUSSION}

The solution of (2) with boundary conditions (3) is obtained with the in-house software. The results are calculated for each case and depicted with charts presented on Figs. 4 and 5. There are obtained main torsional characteristics of the deflected beam, i.e. $\theta(\mathrm{z})$ and $\theta^{\prime}(\mathrm{z})$, which can provide beam loads and stresses with known expressions [10].

The values for $\mathrm{U}_{6}$, for all the cases, have higher values then for $U_{1}, V_{1}, V_{6}$. One may expected this due to highest values of torsional moments involved here upon the geometrical point of application of the inertial forces. The results for the case of high inertial effects on variable section- $\mathrm{V}_{6}$ show that torsional effects are decreased when compared with $\mathrm{U}_{6}$, with emphasis that they are related to maximal values of tangential acceleration. Therefore, concerning the inertial effects only, variability of section of the cantilever beams gives obvious physicall benefits.

Moreover, the charts given in Figs. 4,5 can be used to calculate beam loads and stresses, with limitation of torsional consequences. St Venant shear stresses $\left(\tau_{\theta}\right)$ are proportional to $\theta(\mathrm{z})$, thus maximum values occures at the free end of the cantilever beam. Restraint of warping produces longitudinal stresses and shear stresses. In practice, the warping shear stresses are small enough to be neglected. However, the longitudinal warping stresses $\left(\sigma_{w}\right)$ are of importance and they are greatest at the flange tips with maximum values for clamped end of cantilever beams. Since this is the place where bending is also checked, their calculation is needed. As mentioned in chapter 3.1 the stress state due to global bending is concerned here with $50 \%$ reserve of allowable stress in beam.

Table 2 gives the summary of results for uniform and variable sections for chosen cases. The reduction of the mass with application of variable section is given as in [8], which with average values of $20 \%$ can save operational energy costs of the crane. The results in Table 2 are given for subcases $\mathrm{U}_{6}$ and $\mathrm{V}_{6}$ as they differ in character, along with the fact that they are related to maximal values of tangential acceleration.

Secondly, the effect of vertical force due to weight of payload has to be concerned in calculation of shear stress $\left(\tau_{F V}\right)$ for variable sections due to obvoius shrinkage of the web at free end of the cantilever beam. The results are given in the following table.

Table 2. Beam models and postulation of load cases

\begin{tabular}{|c|c|c|c|c|c|}
\hline & \multicolumn{2}{|c|}{ Uniform - $\mathrm{U}_{6}$} & \multicolumn{3}{|c|}{ Variable $-V_{6}$} \\
\hline \multirow{2}{*}{ CASE } & $\frac{\max }{\sigma_{\mathrm{w}}}$ & $\begin{array}{c}\max \\
\tau_{\theta}\end{array}$ & 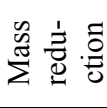 & $\begin{array}{c}\sigma_{\mathrm{w}} \\
\text { decrea- } \\
\text { sment }\end{array}$ & $\begin{array}{c}\max \\
\tau_{F V}\end{array}$ \\
\hline & {$\left[\mathrm{kN} / \mathrm{cm}^{2}\right]$} & {$\left[\mathrm{kN} / \mathrm{cm}^{2}\right]$} & [\%] & [\%] & {$\left[\mathrm{kN} / \mathrm{cm}^{2}\right]$} \\
\hline I & 0.88 & 0.30 & 19.5 & 75 & 0.9 \\
\hline II & 1.22 & 0.41 & 19.5 & 74 & 1.2 \\
\hline III & 1.53 & 0.48 & 19.1 & 73 & 1.4 \\
\hline IV & 2.17 & 0.65 & 19.5 & 71 & 1.7 \\
\hline V & 3.07 & 0.79 & 20.1 & 69 & 2.2 \\
\hline VI & 4.03 & 0.94 & 21.2 & 67 & 2.5 \\
\hline
\end{tabular}

The values for subcase $\mathrm{U}_{6}$ show that St Venant shear stresses $\left(\tau_{\theta}\right)$ goes up to $0.94 \mathrm{kN} / \mathrm{cm}^{2}$ which can be neglected when compared with overall stress. However, values for longitudinal warping stresses $\left(\sigma_{w}\right)$ can be exclusive factor in stress check.

The decrease for longitudinal warping stresses in variable section is high. When compared to overall global bending they have no significant contribution to stress check. The increasment of shear stresses due to weight of payload is in direct relation with shrinkage of the web. It should be included in overall stress check, but they have no influence in design calculation because they occur at free end which is disengaged of the main effects-bending.

\section{CONCLUSION}

Warping torsion is concerned for some typical cantilever beams with variable section, with the goal to show a way of practical optimization of the I-section 
beam considering reduction of the mass with conservation of the structural safety. The effect of horizontal inertial force is studied, as title problem.

It is shown that physical aspect of the inertial load application on variable section gives decrease of torsional consequences. The decreasment of longitudinal warping stresses is remarkably appreciated in overall stress state. The increase of the shear stress hasn't primarily character in safety of the beam.

For uniform sections, the influence of warping stresses due to torsion of the beam can produce stresses with significant influence of the stress check. This is important for jib cranes which are usually unequipped with mechanism to prevent high tangential acceleration while rotating. Also, this calls for attention when the effect of the longitudinal warping stresses is simply rejected in structural analysis.

The variability of the section is recommended as one way of optimization of the beam mass, i.e. for saving the costs in crane exploitation. Forming such sections, the initial costs have no significant share in cost of overall equipment, considering modern technologies of welding machines.

Due to the complexity of the problem, the extension would be to postulate simplified assessment of warping effects in order to facilitate the design problem for practical usage.

\section{ACKNOWLEDGMENT}

This work is a contribution to the Ministry of Education, Science and Technological Development of Republic of Serbia funded project TR 35006.

\section{REFERENCES}

[1] Kurt Thomas and all: Stahl im Hochbau, Verein Deutscher Eisenhuttenleute, Verlag Stahleisen, Dusseldorf, 1969.

[2] Tuma, J.J, Munshi R.K.: Advanced structural analysis, McGraw-Hill, 1971.

[3] Anđelić N., One View to the Optimization of ThinWalled Open Sections Subjected to Constrained Torsion, FME Transactions (2007) 35, pp. 23-28

[4] Anđelic, N., Milosević-Mitić, V., The optimization of a thin walled I-beam subjected to displacement constraint, Proceedings of the 1st International Congress of Serbian Society of Mechanics, Kopaonik, Serbia, pp. 359-366, 2007.
[5] Vlasov, V.Z.: Thin walled elastic beams, Israel Program for Scientific Translations, Jerusalem, Israel, 1961.

[6] Chapra S.C., Canale R.P.: Numerical Methods for Engineers, 6th Edition, Mc-Graw Hill, 2010.

[7] Oliphant T.E., Python for Scientific Computing, Computing in Science and Engineering 9, 90 (2007).

[8] Gašić V., Ćoćić A., Anđelić N.: Warping torsion of non-uniform thin-walled open section at cantilever beams, Proceedings of the XXII International Conference MHCL 17, 2017, Belgrade, pp. 241244.

[9] Cvijović G., Bošnjak S.: The impact of the transition radius lower flange-web on local stress of monorail crane girder, FME Transactions (2017) 45, pp. 543-547.

[10]Petković Z.: Steel Structures in Mechanical Engineering, Faculty of Mechanical EngineeringUniversity of Belgrade, 2005.

\section{УТИЦАЈ ХОРИЗОНТАЛНИХ \\ ИНЕРЦИЈАЛНИХ СИЛА КОД КОНЗОЛНИХ НОСАЧА СА ПРОМЕНЉИВИМ ПОПРЕЧНИМ ПРЕСЕКОМ}

\section{В. Гашић, А. Ћоһић, Н. Анђелић}

У овом раду се анализира утицај хоризонталних инерцијалних сила на конзолне носаче са променљивим попречним пресеком облика Ипрофила. Разматра се варијација пресека која укључује промену висине пресека, као најпрактичније варијанте при пројектовању носача дизалица. Због сложености постављеног проблема који укључује проблем ограниченог увијања, статички одзиви су добијени нумеричким методама.

Модели носача су усвојени према познатим конструкционом препорукама за варијацију носача, са циљем практичне примене код конструкција конзолних дизалица. Поређење резултата је извршено са познатим вредностима ефеката увојног савијања код носача униформног попречног пресека. Са аспекта постављеног проблема и изабраних модела носача, приказане су предности коришћења носача са променљивим попречним пресеком. 